Drama Kings 
The publisher gratefully acknowledges the generous contribution to this book provided by the Asian Studies

Endowment Fund of the University of California Press

Foundation. 


\section{Drama Kings}

Players and Publics in the Re-creation of Peking Opera, I870-I937

\section{Joshua Goldstein}

甲

UNIVERSITY OF CALIFORNIA PRESS

Berkeley - Los Angeles • London 
University of California Press, one of the most distinguished university presses in the United States, enriches lives around the world by advancing scholarship in the humanities, social sciences, and natural sciences. Its activities are supported by the UC Press Foundation and by philanthropic contributions from individuals and institutions. For more information, visit www.ucpress.edu.

University of California Press

Berkeley and Los Angeles, California

University of California Press, Ltd.

London, England

(C) 2007 by The Regents of the University of California

Library of Congress Cataloging-in-Publication Data

Goldstein, Joshua, I965-

Drama kings : players and publics in the re-creation of Peking opera, I870-I937 / Joshua Goldstein.

p. $\mathrm{cm}$.

Includes bibliographical references and index. ISBN 978-0-520-24752-9 (cloth : alk. paper)

I. Theater - China - Beijing - History. 2. Operas, Chinese - China - Beijing - History. 3. Mei, Lanfang, I894-I96I. I. Title.

PN2876.B37G65 2007

792.095 I'I $56-\mathrm{dc} 22$

2006036179

Manufactured in the United States of America

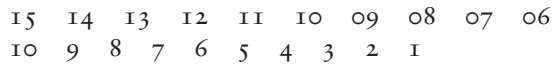

This book is printed on Natures Book, which contains $50 \%$ post-consumer waste and meets the minimum requirements of ANSI/NISO Z39.48-I992 (R I997)

(Permanence of Paper). 